\title{
Deficiency of Vitamin E in the Alveolar Fluid of Cigarette Smokers Influence on Alveolar Macrophage Cytotoxicity
}

Eric R. Pacht, Hisayuki Kaseki, Jeannette R. Mohammed, David G. Cornwell, and W. Bruce Davis Department of Medicine, Division of Pulmonary and Critical Care, and Department of Physiological Chemistry, Ohio State University, Columbus, Ohio 43210

\begin{abstract}
Cigarette smoking produces oxidant-mediated changes in the lung important to the pathogenesis of emphysema. Since vitamin E can neutralize reactive oxygen species and prevent peroxidation of unsaturated lipids, it may constitute an important component of the lung's defense against oxidant injury. To better characterize the antioxidant protective role of vitamin $\mathbf{E}$, young asymptomatic smokers and nonsmokers were evaluated by bronchoalveolar lavage before and immediately after a 3-wk course of oral vitamin E (2,400 IU/d). Smoker alveolar fluid at baseline was relatively deficient in vitamin $\mathbf{E}$ compared with nonsmoker fluid (3.1 \pm 0.7 $\mathrm{ng} / \mathrm{ml}$ vs. $20.7 \pm 2.4 \mathrm{ng} / \mathrm{ml}, P<0.005)$. Although smoker alveolar fluid vitamin $E$ levels increased to $9.3 \pm 2.3 \mathrm{ng} / \mathrm{ml}$ after supplementation, the levels remained significantly lower than nonsmoker baseline levels $(P<0.01)$. This deficiency was explained, in part, by the increased oxidative metabolism of vitamin $E$ to the quinone form in the lungs of smokers compared with nonsmokers. Although the significance of a lower concentration of alveolar fluid vitamin $E$ is unclear, it may compromise the antioxidant protection afforded by the alveolar fluid as it coats the lung's epithelial surface. The protective role of vitamin $\mathbf{E}$ was assessed by cytotoxicity experiments, which demonstrated that the killing of normal rat lung parenchymal cells by smoker alveolar macrophages was inversely related to the vitamin $\mathbf{E}$ content of the parenchymal cells. These findings suggest that vitamin $\mathbf{E}$ may be an important lower respiratory tract antioxidant, and that the deficiency seen in young smokers may predispose them to an enhanced oxidant attack on their lung parenchymal cells.
\end{abstract}

\section{Introduction}

There is increasing evidence that oxidant mechanisms play an important role in the pathogenesis of emphysema in cigarette smokers (1). Cigarette smoke contains a variety of compounds, both in the particle fraction and the gaseous phase, that function as oxidants (2-4). Furthermore, cigarette smoking induces a striking increase in lung inflammatory cells, principally alveolar macrophages and neutrophils $(5,6)$, which are potent producers of reactive oxygen species, including superoxide anion $\left(\mathrm{O}_{2}^{-}\right)$, hydrogen peroxide $\left(\mathrm{H}_{2} \mathrm{O}_{2}\right)$, hydroxyl radical $\left(\mathrm{OH}^{\circ}\right)$, and myelope-

Address reprint requests to Dr. Pacht, N-325 Means Hall, 1655 Upham Drive, Columbus, $\mathrm{OH} 43210$.

Received for publication 18 June 1985 and in revised form 1 November 1985.

J. Clin. Invest.

(C) The American Society for Clinical Investigation, Inc. 0021-9738/86/03/0789/08 \$1.00

Volume 77, March 1986, 789-796 roxidase products $(7,8)$. Chronic exposure to these oxidants may contribute to the lesion of emphysema by damaging both the connective tissue matrix and the parenchymal cells of the lung. Evidence that oxidants damage the extracellular connective tissue matrix of the lung is chiefly derived from studies demonstrating that both cigarette smoke $(4,9,10)$ and activated phagocytes (11) are capable of oxidative inactivation of alpha1-antitrypsin, the major antielastase in the lung (12). A functional deficiency of alpha-1-antitrypsin may lead to unimpeded elastolytic degradation of the connective tissue matrix of the lung (13). Evidence that oxidants damage the cellular components of the alveolar wall is derived from two sources. First, smoker alveolar macrophages have enhanced oxidative metabolism (14, 15) and cytotoxic potential for lung parenchymal cells (14) and fibroblasts (15). Second, cigarette smoke increases peroxidation of lipids in the lungs of experimental animals (16). If the phospholipids of cellular membranes are subjected to extensive peroxidation, they undergo degradation that leads to structural damage and eventual cell death (17).

Since cigarette smoking seems to produce oxidant lung injury, one possible therapeutic approach involves the augmentation of antioxidant protection at the level of the alveolar structures. Vitamin $\mathrm{E}$ is a naturally occurring antioxidant that is virtually free of toxicity in man $(18,19)$. Its antioxidant properties reflect its ability to neutralize free radicals, including toxic oxygen intermediates, thereby preventing peroxidation of unsaturated lipids $(20,21)$. Numerous animal studies have demonstrated that vitamin $E$ is an important determinant of the lung's susceptibility to injury by various oxidants, including hyperoxia $(22,23), \mathrm{NO}_{2}(24,25)$, ozone (26-28), paraquat (29), nitrofurantoin (30), and other oxidizing agents $(31,32)$. Oxidizing substances in cigarette smoke also produce lipid peroxidation (16), and Chow et al. (33) have shown that vitamin E-deficient rats exposed to cigarette smoke die prematurely compared with control animals.

Although vitamin $\mathrm{E}$ has been extensively evaluated in animal models of oxidant lung injury, little quantitative information is available about its role in human lung disease. In the present study, smokers and nonsmokers were evaluated by bronchoalveolar lavage $(\mathrm{BAL})^{1}$ before and immediately after a 3-wk course of oral vitamin $\mathrm{E}$. These studies provide evidence that the lower respiratory tract fluid of smokers is relatively deficient in vitamin E. This decreased level of vitamin $E$ is at least partially explained by the greater oxidation of vitamin $\mathrm{E}$ in the lungs of smokers compared with nonsmokers. The possible significance of deficient alveolar fluid vitamin $\mathrm{E}$ levels is underscored by cytotoxicity experiments in which smoker alveolar macrophages demonstrate enhanced killing of vitamin E-deficient lung parenchymal cells from experimental animals.

1. Abbreviations used in this paper: BAL, bronchoalveolar lavage; HPLC, high performance liquid chromatography; SOD, superoxide dismutase. 


\section{Methods}

Subject groups. Young cigarette smokers $(n=7)$ with no history of cough or sputum production were screened by history, physical examination, and chest roentgenogram. Routine spirometry revealed a normal forced vital capacity (FVC), forced expiratory volume in $1 \mathrm{~s}$ (FEV1), and a FEV 1/FVC ratio of $>80 \%$ in all subjects. There were five females and two males with a mean age of $32.7 \pm 3.3$ yr. Subjects had smoked an average of $15.0 \pm 3.9$ pack years (packs of cigarettes smoked per day times years smoked), and were instructed to continue their respective smoking habits, including smoking immediately before bronchoscopy. As a relevant control group, nonsmokers $(n=12)$ with a mean age of $22.8 \pm 1.1$ yr were evaluated under a similar protocol. All subjects gave informed consent and were studied under an approved protocol of The Ohio State University Human Subjects Review Committee.

Study design. The protocol was designed as a single blind, crossover study comparing placebo and vitamin E ( $d l-\alpha$-tocopheryl acetate). Placebo and vitamin $E$ capsules were indistinguishable, and were a generous gift of the R. P. Scherer Corp. (Clearwater, FL). Each subject took a 3-wk course of placebo followed by a 3-wk course of vitamin $E(2,400 \mathrm{IU} / \mathrm{d})$. Since elevated tissue levels of vitamin $\mathrm{E}$ may persist for variable periods of time after supplementation (34), all subjects took placebo first, although they were unaware of the order of the medications. At the end of each 3-wk period, serum and BAL samples were collected and stored at $-70^{\circ} \mathrm{C}$ until analysis. Henceforth, results obtained after the 3-wk course of placebo will be called baseline, and results obtained after the 3-wk course of vitamin $E$ will be called supplemented.

$B A L$. Fiberoptic bronchoscopy and BAL were performed as previously described (5). To ensure uniformity, all procedures were done by the same bronchoscopist (Dr. Pacht). All subjects were studied on room air and did not receive supplemental oxygen. Briefly, after local anesthesia with $2 \%$ xylocaine, a flexible fiberoptic bronchoscope (model BF-B2, Olympus Corp. of America, New Hyde Park, NY) was passed transnasally and wedged into segments of the right lung. Two segments were lavaged, each with $100 \mathrm{ml}$ of $0.9 \%$ saline in $20-\mathrm{ml}$ aliquots, for a total of $200 \mathrm{ml}$.

The recovered BAL fluid was strained through coarse-mesh surgical gauze and centrifuged $(500 \mathrm{~g}, 15 \mathrm{~min})$ to separate cellular and noncellular components. The BAL supernates were buffered with $1.0 \mathrm{M}$ Tris $\mathrm{HCl}$ $(\mathrm{pH}=7.4)$ to a final concentration of $0.05 \mathrm{M}$ Tris and stored at $-70^{\circ} \mathrm{C}$ in small-volume aliquots until further analysis. The cell pellets were washed twice in Hanks' balanced salt solution (HBSS) without $\mathrm{Ca}^{++}$or $\mathrm{Mg}^{++}$and counted by hemocytometer. A small aliquot was cytocentrifuged ( $35 \mathrm{~g}, 10 \mathrm{~min}$ ), air-dried, and stained by modified Wright-Giemsa stain. A differential count was performed on a minimum of 300 cells. Viability was assessed by measuring the ability of alveolar macrophages to exclude $0.2 \%$ trypan blue.

Animal studies. Adult female Sprague Dawley rats weighing 170$210 \mathrm{~g}(n=6)$ were randomly divided into two groups. One group was fed a specially prepared diet completely devoid of vitamin E for 20-23 wk. The second group was given the same diet supplemented with 66 IU vitamin E/ $\mathrm{kg}$ of chow for 20-23 wk. The diet devoid of vitamin $\mathrm{E}$ followed the formulation of Draper et al. (35), and was supplied by ICN Pharmaceutical Co. (Cleveland, $\mathrm{OH}$ ). Rats were killed, the chest and abdominal cavities were opened, and blood was immediately drawn from the abdominal aorta into a heparin-coated syringe. The trachea was cannulated with a 14-g catheter and the lungs removed en bloc from the chest. The left lung, trachea, and cannula were immediately used in cytotoxicity experiments (see below). The right lung, liver, adrenal gland, adipose tissue, and ovary were weighed, wrapped in aluminum foil, and placed on ice for vitamin $\mathrm{E}$ studies (see below). In additional rats ( $n$ $=6$ ), the right mainstem bronchus was ligated and the left lung underwent BAL. This lung was slowly and evenly inflated with $5 \mathrm{ml}$ of $0.9 \%$ saline by means of a $10-\mathrm{ml}$ syringe attached to the tracheal catheter. The lung was then inverted and fluid aspirated by gentle syringe suction. Approximately $3 \mathrm{ml}$ was recovered from each animal. The right lung was weighed, wrapped in aluminum foil, and placed on ice for vitamin $E$ studies (see below).

Additional experiments were performed to determine the distribution and metabolism of vitamin E. A third group of rats $(n=3)$ consisted of animals maintained on a diet devoid of vitamin $\mathrm{E}$ for $20 \mathrm{wk}$ who were given a large oral dose of vitamin $\mathrm{E}$ (16.7 IU, which is equivalent to $5,000 \mathrm{IU}$ in a $60-\mathrm{kg}$ man) $24 \mathrm{~h}$ before killing. Tissues were harvested and used for measurements of vitamin $\mathrm{E}$ and its major oxidative metabolite, vitamin $\mathrm{E}$ quinone (see below).

Vitamin $E$ and vitamin E quinone assay. Vitamin $\mathrm{E}$ and vitamin $\mathrm{E}$ quinone levels were determined by high performance liquid chromatography (HPLC) $(36,37)$ on the following tissues: (1) human and rat serum (100- $\mu$ l sample); (2) human and rat unconcentrated BAL fluid (4-8-ml sample); (3) human alveolar macrophages (2.5-7.5 $\times 10^{6}$ cells); (4) rat tissues ( $\sim 100$-mg samples of lung, liver, adrenal, ovary, and adipose tissue). Alveolar macrophages were suspended in $1 \%$ ascorbic acid (Fisher Scientific Co., St. Louis, MO) in ethanol (Fisher Scientific Co.) solution and sonicated for $1 \mathrm{~min}$ at $45 \mathrm{~W}$ on an Artek 150 sonic dismembrator (Artek System Co., Farmingdale, NY). Freshly harvested rat tissues (see above) were placed in 3\% pyrogallol (Fisher Scientific Co.) in ethanol solution and anaerobically homogenized for $30 \mathrm{~s}$.

The saponification and extraction of vitamin $E$ from the above samples was performed according to the method of Hatam and Kayden (38). Briefly, samples were placed in teflon-stoppered borosilicate glass tubes and treated with $2 \mathrm{ml}$ of either $1 \%$ ascorbic acid in ethanol or $3 \%$ pyrogallol in ethanol. After heating $2 \mathrm{~min}$ at $70^{\circ} \mathrm{C}, 300 \mu \mathrm{l}$ of a saturated $\mathrm{KOH}$ (Fisher Scientific Co.) solution was added, and the tubes were incubated for $30 \mathrm{~min}$ at $70^{\circ} \mathrm{C}$. The tubes were cooled on ice, and $1 \mathrm{ml}$ of distilled water and $4 \mathrm{ml}$ of hexane (Fisher Scientific Co.) was added. Samples were vortexed vigorously and centrifuged at $1,600 \mathrm{~g}$ for $10 \mathrm{~min}$. Exactly $3.6 \mathrm{ml}$ of the upper hexane layer was removed, placed in a small borosilicate glass tube, and evaporated to dryness over nitrogen gas at $35^{\circ} \mathrm{C}$. The samples were redissolved in $4 \mathrm{ml}$ methanol and filtered through a $0.22-\mu \mathrm{m}$ filter (Millipore Corp., Bedford, MA). Samples were stored in glass screw top vials under nitrogen at $-70^{\circ} \mathrm{C}$ until analysis by HPLC.

Vitamin $\mathrm{E}$ and vitamin $\mathrm{E}$ quinone were measured using a Beckman model 334 gradient liquid chromatograph (Beckman Instruments, Inc., Palo Alto, CA) equipped with a Beckman 164 variable wavelength detector and an Altex model C-RIA integrator-recorder (Beckman Instruments, Inc.). The analytical reverse-phase column was $55 \mathrm{~cm}$ and consisted of two 15-cm Altex Ultrasphere ODS columns $(4.6 \times 150 \mathrm{~mm})$ and one $25-\mathrm{cm}$ Altex Ultrasphere ODS column $(4.6 \times 250 \mathrm{~mm})$. Vitamin $E$ and vitamin $E$ quinone were measured using isocratic elution with $100 \%$ methanol at a flow rate of $1.2 \mathrm{ml} / \mathrm{min}$. Monitoring conditions for vitamin $\mathrm{E}$ and vitamin $\mathrm{E}$ quinone were ultraviolet $294 \mathrm{~nm}$ and ultraviolet $254 \mathrm{~nm}$, respectively. Retention times were 14.3 and $20.0 \mathrm{~min}$ for vitamin $\mathrm{E}$ quinone and vitamin $\mathrm{E}$, respectively. Calibration curves were established for vitamin $E$ and vitamin $E$ quinone from measured peak areas of their respective chromatograms using standards supplied by Eastman Kodak Co. (Rochester, NY). The minimum amounts of vitamin $E$ and vitamin E quinone that could be detected were 2 and $1 \mathrm{ng}$, respectively. Results were expressed as $\mu \mathrm{g} / \mathrm{ml}$ of serum, $\mathrm{ng} / \mathrm{ml}$ of unconcentrated BAL fluid, $\mathrm{ng} / 10^{6}$ alveolar macrophages, and $\mu \mathrm{g} / \mathrm{g}$ of wet rat tissue. Vitamin $\mathrm{E}$ quinone to vitamin $\mathrm{E}$ ratios were also calculated and expressed as a percentage.

Measurement of superoxide anion released by alveolar macrophages. To determine if vitamin E supplementation could inhibit production of $\mathrm{O}_{2}^{-}$by smoker alveolar macrophages, $\mathrm{O}_{2}^{-}$release was assayed by previously described techniques (39). This assay depends on the reduction of type VI ferricytochrome C (Sigma Chemical Co., St. Louis, MO) by $\mathrm{O}_{2}^{-}$. Briefly, smoker alveolar macrophages $\left(1 \times 10^{6}\right.$ cells $\left./ \mathrm{ml}\right)$ in RPMI (Gibco, Grand Island, NY) were placed in 24-well tissue culture plates (BectonDickinson \& Co., Oxnard, CA) and allowed to adhere for $60 \mathrm{~min}$ at $37^{\circ} \mathrm{C}$. Each well was washed twice with $\mathrm{HBSS}$ without $\mathrm{Ca}^{++}$and $\mathrm{Mg}^{++}$ to remove the culture medium, and $2 \mathrm{ml}$ of HBSS containing ferricytochrome $\mathrm{C}(100 \mu \mathrm{M})$ was added back to each well. Some wells also contained $50 \mu \mathrm{g} / \mathrm{ml}$ of superoxide dismutase (SOD, Sigma Chemical Co.) or $100 \mathrm{ng} / \mathrm{ml}$ of phorbol myristate acetate (Sigma Chemical Co.). All wells were incubated at $37^{\circ} \mathrm{C}$ for $30 \mathrm{~min}$ and then placed immediately on ice. Blanks contained all components of the reaction mixture except alveolar macrophages. Supernatants from each well were removed and 
centrifuged at $1,600 \mathrm{~g}$ for $20 \mathrm{~min}$ and assayed at $550 \mathrm{~nm}$ on a DU-8 spectrophotometer (Beckman Instruments, Inc.). Absorbance of SOD containing wells was subtracted to yield SOD-inhibitable ferricytochrome $C$ reduction. Results were calculated using a $\Delta \mathrm{E}_{\mathrm{mM}}^{550}$ of $18.5(39,40)$ and expressed as nanomoles $\mathrm{O}_{2}^{-}$released per $10^{6}$ alveolar macrophages per $30 \mathrm{~min}$.

Effect of dietary vitamin $E$ on rat lung susceptibility to injury. To determine if different lung levels of vitamin $E$ alter lung susceptibility to alveolar macrophage-induced cytotoxicity, the left lungs from both groups of rats were compared in an in vitro cytotoxicity assay system as described by Martin et al. (41). The left lung was inflated with $\sim 4 \mathrm{ml}$ of $0.6 \%$ low-melting point agarose (Bethesda Research Laboratories, Inc., Gaithersburg, MD) and placed in HBSS at room temperature to solidify the agarose. The agarose-filled lungs were then sectioned into 200-400$\mu \mathrm{m}$ thick slices with a tissue slicer, and the resulting parenchymal slices cut into explants with an average weight of 1-2 mg. To label the lung parenchymal cells, the explants were washed in HBSS and incubated for $90 \mathrm{~min}$ in $5 \% \mathrm{CO}_{2}, 37^{\circ} \mathrm{C}$, in $10 \mathrm{ml}$ of assay medium (RPMI-1640 with $25 \mathrm{mM}$ Hepes buffer, $\mathrm{pH} 7.4,1.5 \%$ bovine serum albumin [Gibco], penicillin [100 U/ml], and streptomycin [100 $\mu \mathrm{g} / \mathrm{ml}]$ ) containing 100 $\mu \mathrm{Ci} / \mathrm{ml}{ }^{51}$ chromium (sodium chromate, Amersham Corp., Arlington Heights, IL). The labeled explants were then washed repeatedly in unlabeled media, weighed, and individually co-cultured in $1 \mathrm{ml}$ of assay media to which had been added smoker alveolar macrophages at effector to target cell ratios of $5: 1$. After $18 \mathrm{~h}$ at $5 \% \mathrm{CO}_{2}, 37^{\circ} \mathrm{C}$, all tubes were centrifuged at $800 \mathrm{~g}$ for $5 \mathrm{~min}$. The upper $0.5 \mathrm{ml}$ of each supernatant was harvested, placed in a separate tube, and counted in a gamma counter. The percent ${ }^{51} \mathrm{Cr}$ released into the media was then determined as the ratio (dpm released into the media/total dpm of media plus explant) $\times 100 \%$. Using these ratios, alveolar macrophage cytotoxicity was calculated as a cytotoxic index by the following formula: $A-B / C-B$ $\times 100 \%$, where $A=$ percent ${ }^{51} \mathrm{Cr}$ released from the test explant incubated with alveolar macrophages; $B=$ percent ${ }^{51} \mathrm{Cr}$ released spontaneously from control explants; and $C=$ the maximum percent ${ }^{51} \mathrm{Cr}$ released from control explants incubated in a solution of $2 \%$ Triton X. Spontaneous release of ${ }^{51} \mathrm{Cr}$ from control explants $(B)$ was $<30 \%$ in all experiments, and was not significantly different in normal or deficient rats. All experiments were performed in duplicate.

Statistical methods. All data was expressed as a mean and standard error of the mean. Paired data was compared using two-way analysis of variance. Unpaired data was analysed with the $t$ test. Differences were assumed to be significant if $P<0.05$.

\section{Results}

$B A L$. BAL was well tolerated by all subjects. There was no significant difference in the percentage of instilled saline recovered between smokers and nonsmokers $(52.4 \pm 2.7$ vs. $56.6 \pm 2.6 \%, P$ $>0.1$ ). Vitamin $\mathrm{E}$ had no discernible effect on cell counts or cell differentials in either group (Table I). Total cell counts were markedly increased in smokers compared with nonsmokers. Al- veolar macrophage counts, expressed as cells $\times 10^{3} / \mathrm{ml}$ of unconcentrated BAL fluid, were also significantly increased in smokers compared with nonsmokers, both at baseline (713 \pm 125 vs. $123 \pm 16, P<0.005)$ and after vitamin $E(732 \pm 114$ vs. $118 \pm 16, P<0.005)$. This sixfold increase in alveolar macrophages in smokers has previously been noted by other investigators $(5,15)$. There were also no significant differences in lavage cell differentials between smokers and nonsmokers, with alveolar macrophages comprising $>90 \%$ of recovered cells under both treatment conditions (Table 1). When assessed by trypan blue exclusion, the viability of both smoker and nonsmoker alveolar macrophages was always $>90 \%$.

Vitamin E levels. Serum levels of vitamin E increased significantly in both groups after supplementation (Table II). The serum level in smokers increased from $8.8 \pm 0.7 \mu \mathrm{g} / \mathrm{ml}$ at baseline to $20.6 \pm 2.9 \mu \mathrm{g} / \mathrm{ml}$ after vitamin E. A similar increase (10.5 $\pm 1.6-$ $22.7 \pm 1.9 \mu \mathrm{g} / \mathrm{ml}$ ) was seen in nonsmokers. Serum vitamin E levels (baseline and supplemented) did not differ significantly between smokers and nonsmokers ( $P>0.1$, both comparisons), and are consistent with previously reported values (42-44).

In contrast to serum values, BAL fluid levels of vitamin E were significantly lower in smokers compared with nonsmokers (Table III). Vitamin E was undetectable $(<2 \mathrm{ng} / \mathrm{ml})$ in the BAL fluid of five of seven smokers at baseline. If these five smokers at baseline are generously assumed to have BAL vitamin E levels of $2 \mathrm{ng} / \mathrm{ml}$ (the lower limit of the assay), then the average vitamin E content of the BAL fluid is $3.1 \pm 0.7 \mathrm{ng} / \mathrm{ml}$ for the seven smoking subjects. Corresponding baseline values for nonsmoker BAL fluid were significantly higher $(20.7 \pm 2.4 \mathrm{ng} / \mathrm{ml}, P<0.005)$. After supplementation, vitamin $\mathrm{E}$ was easily measured in the BAL fluid of all seven smokers and averaged $9.3 \pm 2.3 \mathrm{ng} / \mathrm{ml}(P<0.05$ compared with baseline). Despite this increase, the level remained significantly less than either the baseline or supplemented BAL fluid levels of nonsmokers ( $P<0.01$, both comparisons). Thus, smoker BAL fluid was relatively deficient in vitamin $E$, and the level of vitamin $E$ was only partially replenished by oral supplementation.

Although the alveolar macrophage vitamin E level in smokers was approximately twice the level of nonsmokers, both at baseline and following vitamin $\mathrm{E}$, the differences did not reach statistical significance $(P>0.1$, Table IV). Furthermore, vitamin E supplementation did not augment either smoker or nonsmoker alveolar macrophage levels above baseline values.

Additional studies in normal rats demonstrated a linear correlation between BAL vitamin $\mathrm{E}$ level and lung tissue vitamin E content ( $r=0.96, P<0.01$, data not shown).

Vitamin E quinone levels. Additional information about the

Table I. BAL Cell Counts and Differentials

\begin{tabular}{|c|c|c|c|c|c|c|c|c|c|c|}
\hline \multirow[b]{2}{*}{ Group } & \multicolumn{2}{|c|}{ Total cell count $\left(\times 10^{6}\right)$} & \multicolumn{2}{|c|}{ Alveolar macrophages (\%) } & \multicolumn{2}{|c|}{ Lymphocytes (\%) } & \multicolumn{2}{|c|}{ Neutrophils (\%) } & \multicolumn{2}{|c|}{ Eosinophils (\%) } \\
\hline & $\mathbf{B}^{*}$ & $\mathbf{S} \ddagger$ & B & $\mathbf{S}$ & B & $\mathbf{s}$ & B & $\mathbf{S}$ & B & $\mathbf{S}$ \\
\hline \multicolumn{11}{|l|}{ Smokers } \\
\hline$(n=7)$ & $78.0 \pm 16.2 \S$ & $78.4 \pm 16.2 \S$ & $94.6 \pm 1.7$ & $92.7 \pm 1.3$ & $1.6 \pm 0.5$ & $3.7 \pm 1.5$ & $2.6 \pm 1.2$ & $1.9 \pm 0.8$ & $1.1 \pm 0.5$ & $1.7 \pm 0.7$ \\
\hline \multicolumn{11}{|l|}{ Nonsmokers } \\
\hline$(n=12)$ & $16.5 \pm 2.3$ & $14.4 \pm 2.2$ & $94.0 \pm 1.7$ & $91.8 \pm 2.0$ & $5.7 \pm 2.1$ & $7.1 \pm 1.9$ & $0 \pm 0$ & $0.6 \pm 0.2$ & $0.2 \pm 0.2$ & $0.6 \pm 0.2$ \\
\hline
\end{tabular}

* B, baseline. $¥ \mathrm{~S}$, supplemented. $\S P<0.03$ when compared with corresponding nonsmoker values. 
Table II. Serum Vitamin E and Vitamin E Quinone Levels

\begin{tabular}{|c|c|c|c|c|}
\hline \multirow[b]{2}{*}{ Condition } & \multicolumn{2}{|l|}{ Smoker } & \multicolumn{2}{|l|}{ Nonsmoker } \\
\hline & $\begin{array}{l}\text { Vitamin } \\
\mathrm{E}^{*}\end{array}$ & $\begin{array}{l}\text { Vitamin E } \\
\text { quinone* }\end{array}$ & $\begin{array}{l}\text { Vitamin } \\
\mathrm{E}^{*}\end{array}$ & $\begin{array}{l}\text { Vitamin E } \\
\text { quinone* }\end{array}$ \\
\hline Baseline & $8.8 \pm 0.7$ & $0.08 \pm 0.02$ & $10.5 \pm 1.6$ & $0.09 \pm 0.03$ \\
\hline \multicolumn{5}{|l|}{ Following } \\
\hline supplementation & $20.6 \pm 2.9$ & $0.08 \pm 0.02$ & $22.7 \pm 1.9$ & $0.15 \pm 0.03$ \\
\hline
\end{tabular}

* Expressed as micrograms per milliliter.

distribution and metabolism of vitamin $\mathrm{E}$ was provided by measurement of its principal oxidative metabolite, vitamin $E$ quinone (Tables II-IV). Serum levels of vitamin E quinone were quite low $(<0.15 \mu \mathrm{g} / \mathrm{ml})$ in all four study groups (Table II). Moreover, the ratio, vitamin $\mathrm{E}$ quinone/vitamin $\mathrm{E}$, was $<1.1 \%$ in all four groups (Fig. 1).

In contrast to serum, BAL fluid from all subjects contained concentrations of vitamin $\mathrm{E}$ quinone that represented a significant portion of total vitamin E content (Fig. 1). This suggests that vitamin $E$ is oxidized in the relatively high partial pressure oxygen environment of the lung. The ratio, vitamin E quinone/ vitamin $\mathrm{E}$, was at least $35 \%$ in all four groups, and was statistically greater than all corresponding serum ratios $(P<0.05$, all comparisons). Consistent with the observation that nonsmokers had higher BAL fluid vitamin $\mathrm{E}$ than smokers, nonsmokers also had higher BAL fluid vitamin E quinone levels than smokers (Table III). This relationship was maintained both at baseline and after supplementation ( $P<0.05$, both comparisons). Of greater relevance was the marked increase in the vitamin $\mathrm{E}$ quinone/vitamin $\mathrm{E}$ ratio in the BAL fluid of smokers at baseline (Fig. 1). This elevated ratio, $108 \pm 26 \%$ in smokers at baseline, was significantly greater than the ratios of the other three study groups ( $P<0.05$, all comparisons). After supplementation, the absolute value of smoker BAL fluid vitamin $E$ increased (Table III), while the ratio, vitamin $\mathrm{E}$ quinone/vitamin $\mathrm{E}$, markedly decreased from 108 to $51 \%$, a value not significantly different from either baseline or supplemented nonsmoker ratios $(P>0.1$, both comparisons). Thus, the following conclusions can be drawn based on the measurement of vitamin $E$ and vitamin $E$ quinone in BAL fluid: (a) a significant portion of BAL vitamin $\mathrm{E}$ is oxidatively metabolized to the quinone form in the human lung; and (b) the relative deficiency of vitamin E in the BAL fluid of smokers may be partially explained by a greater oxidation of vitamin $E$ in the lower respiratory tract of smokers compared with nonsmokers.

Alveolar macrophage vitamin E'quinone levels were not significantly different in the various treatment groups (Table IV).

Table III. BAL Fluid Vitamin E and Vitamin E Quinone Levels

\begin{tabular}{|c|c|c|c|c|}
\hline \multirow[b]{2}{*}{ Condition } & \multicolumn{2}{|l|}{ Smoker } & \multicolumn{2}{|l|}{ Nonsmoker } \\
\hline & $\begin{array}{l}\text { Vitamin } \\
\mathbf{E}^{*}\end{array}$ & $\begin{array}{l}\text { Vitamin E } \\
\text { quinone* }\end{array}$ & Vitamin $\mathrm{E}^{*}$ & $\begin{array}{l}\text { Vitamin } \mathrm{E} \\
\text { quinone* }\end{array}$ \\
\hline Baseline & $3.1 \pm 0.7$ & $2.7 \pm 0.5$ & $20.7 \pm 2.4$ & $6.8 \pm 2.6$ \\
\hline \multicolumn{5}{|l|}{ Following } \\
\hline supplementation & $9.3 \pm 2.3$ & $3.6 \pm 0.9$ & $29.6 \pm 5.3$ & $10.4 \pm 2.0$ \\
\hline
\end{tabular}

* Expressed as nanograms per milliliter unconcentrated BAL fluid.
Table IV. Alveolar Macrophage Vitamin E and Vitamin E Quinone Levels

\begin{tabular}{llllll}
\hline & Smoker & & & Nonsmoker & \\
\cline { 2 - 3 } \cline { 5 - 6 } Condition & Vitamin $\mathrm{E}^{*}$ & $\begin{array}{c}\text { Vitamin } \mathrm{E} \\
\text { quinone* }\end{array}$ & Vitamin $\mathrm{E}^{*}$ & $\begin{array}{l}\text { Vitamin } \mathrm{E} \\
\text { quinone }\end{array}$ \\
\hline $\begin{array}{l}\text { Baseline } \\
\begin{array}{l}\text { Following } \\
\text { supplementation }\end{array}\end{array}$ & $131 \pm 37$ & $3.6 \pm 1.1$ & $78.4 \pm 25.9$ & $1.2 \pm 0.3$ \\
& $107 \pm 20$ & $6.0 \pm 1.6$ & $52.4 \pm 1.8$ & $5.3 \pm 3.1$ \\
\hline
\end{tabular}

* Expressed as $\mathrm{ng} / 10^{6}$ cells.

Vitamin E quinone/vitamin E ratios ranged from a low of $1.7 \%$ in nonsmokers at baseline to a high of $10.4 \%$ in nonsmokers after supplementation. Thus the ratio, vitamin $\mathrm{E}$ quinone/vitamin E, in alveolar macrophages was intermediate between the low serum ratios and the high BAL fluid ratios.

The elevated vitamin $\mathrm{E}$ quinone/vitamin $\mathrm{E}$ ratio in human BAL fluid was confirmed by a series of animal experiments. The BAL fluid of rats, maintained on a diet containing 66 IU vitamin $\mathrm{E} / \mathrm{kg}$ chow, had a vitamin $\mathrm{E}$ quinone/vitamin $\mathrm{E}$ ratio of $20.6 \pm 0.6 \%$. Further experiments were performed in an attempt to document the rapid oxidation of vitamin $E$ in lung tissue. Rats, maintained on a diet devoid of vitamin $E$, were given an oral pharmacologic dose of vitamin E (16.7 IU) $24 \mathrm{~h}$ before killing. Table $\mathrm{V}$ displays the vitamin $\mathrm{E}$ quinone/vitamin $\mathrm{E}$ ratios for serum, lung, liver, adrenal, ovary, and adipose tissue in these acutely repleted animals. Although vitamin E could be measured in all of the tissues, only lung, liver, and adrenal gland had detectable levels of vitamin $\mathrm{E}$ quinone. Furthermore, vitamin $\mathrm{E}$ quinone/vitamin $\mathrm{E}$ ratios for lung averaged $3.5 \pm 0.8 \%$, well in excess of all other tissues examined. Thus, these animal experiments with both alveolar fluid and lung tissue confirm the observation in humans that a significant portion of vitamin $E$ is oxidatively metabolized in the lung.

Effect of vitamin $E$ on superoxide anion production by alveolar macrophages. Superoxide anion release from alveolar macrophages (expressed as nanomoles $\mathrm{O}_{2}^{-}$released per $10^{6}$ cells per $30 \mathrm{~min}$ ) was not significantly different, whether it was measured with subjects at baseline or after vitamin $E$ supplementation (baseline 8.6 \pm 1.4 , supplemented 9.1 $\pm 1.7, P>0.1$ ). After stimulation of the alveolar macrophages by PMA, there was also no significant difference (baseline 16.7 \pm 1.0 , supplemented 14.2 $\pm 1.5, P>0.1)$.

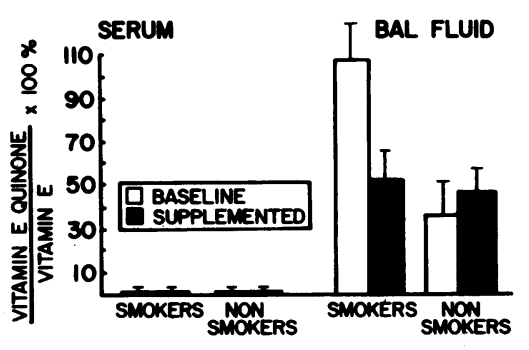

Figure 1. Vitamin E quinone/vitamin $\mathrm{E}$ ratios in serum and BAL fluid. Serum ratios are $<1.1 \%$ in all four groups, which is significantly less than corresponding BAL fluid ratios $(P<0.05$, all comparisons). Smokers at baseline had a significantly higher BAL fluid ratio than the other three groups $(P<0.05$, all comparisons). 
Table V. Vitamin E Quinone/Vitamin E Ratios after an Acute Dose of Vitamin E in Chronically Vitamin E-deficient Rats*

\begin{tabular}{llllll} 
Serum & Lung & Liver & Adrenal & Ovary & $\begin{array}{l}\text { Adipose } \\
\text { tissue }\end{array}$ \\
\hdashline 0 & $3.5 \pm 0.8$ & $0.09 \pm 0.07$ & $1.3 \pm 0.3$ & 0 & 0
\end{tabular}

* Results expressed as percentages.

Effect of vitamin E on lung susceptibility to injury. Since oral vitamin E supplementation was unable to decrease superoxide anion release from the effector cell (smoker alveolar macrophages), additional studies were designed to determine if the susceptibility of the target cell (rat lung parenchymal cells) to oxidant-mediated injury could be altered by dietary vitamin $\mathrm{E}$. Thus, rats were randomly divided into two groups and maintained either on a diet devoid of vitamin $\mathrm{E}$ or a diet containing a normal amount of vitamin $E$. The level of vitamin $E$ in the lungs of normally supplemented rats was significantly greater than the level in vitamin E-deficient rats $(4.8 \pm 0.2 \mu \mathrm{g} / \mathrm{g}$ wet lung tissue vs. $1.2 \pm 0.1 \mu \mathrm{g} / \mathrm{g}$ wet lung tissue, $P<0.005$, Fig. 2$)$. When lung explants prepared from these two groups of animals were incubated with smoker alveolar macrophages, cytotoxicity correlated inversely with the lung level of vitamin E (Fig. 2). Smoker alveolar macrophages were significantly more cytotoxic for lung explants prepared from the vitamin E-deficient rats than lung explants prepared from rats on a normal diet $(43.5 \pm 2.1$ vs. $15.7 \pm 3.5 \%, P<0.005)$.

\section{Discussion}

Oxidants in cigarette smoke and those released by inflammatory cells recruited to the lung play an important role in the pathogenesis of emphysema (1). The antioxidant, vitamin E, has been employed in numerous animal experiments to neutralize oxygencentered free radicals and decrease lung susceptibility to oxidant injury (22-32). Vitamin $\mathrm{E}$ has also been used with some success in two oxidant-mediated disorders of humans: certain hemolytic anemias (45) and retrolental fibroplasia of the neonate (46). The present study suggests a possible role for vitamin $E$ in the lung's defense against cigarette smoke. Young asymptomatic cigarette smokers were found to have a relative deficiency of vitamin $\mathrm{E}$ in their alveolar fluid, which could only be partially replenished by oral supplementation. Although the mechanism for this de-
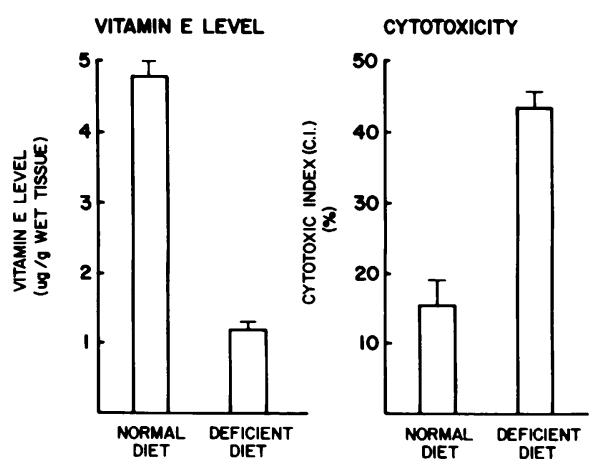

Figure 2. Effect of lung levels of vitamin E on susceptibility of lung parenchyma to alveolar macrophage mediated cytotoxicity. There is an inverse relationship between lung vitamin $\mathrm{E}$ level and cytotoxicity. ficiency is uncertain, evidence is presented that the oxidative metabolism of vitamin $\mathrm{E}$ to the quinone form occurs to a much greater extent in smokers compared with nonsmokers. Thus, the increased oxidant burden in the lungs of smokers is accompanied by a decrease in antioxidant protection characterized by lower levels of alveolar fluid vitamin $\mathrm{E}$. The significance of this oxidant-antioxidant imbalance was demonstrated by cytotoxicity experiments in which smoker alveolar macrophages exhibited enhanced killing of vitamin E-deficient lung parenchymal cells.

If vitamin $\mathrm{E}$ protects the lung against cigarette smoke, the mechanism probably relates to its ability to prevent lipid peroxidation. Lentz and DiLuzio (16) incubated sonicates of rabbit alveolar macrophages with an aqueous extract of cigarette smoke and demonstrated peroxidation of lipids, as measured by the accumulation of malonaldehyde. Further experiments also demonstrated a dose-related increase in malonaldehyde production when lipid surface active material was incubated with aqueous extracts of cigarette smoke. Numerous other investigators have demonstrated that lipid peroxidation occurs with a variety of oxidant exposures, and the amount of peroxidation is inversely related to the vitamin $E$ content of the affected tissue $(24,26,27,31,32,47,48)$. Thus, vitamin $\mathrm{E}$ has a potential role in preventing cigarette smoke-induced peroxidation of lung lipids.

One of the most intriguing findings of the present study was the low level of alveolar fluid vitamin $\mathrm{E}$ in smokers. It is conceivable that these low alveolar fluid levels are the result of an increased demand for this antioxidant by lung tissue exposed to a high level of oxidants. In this context, previous investigators have demonstrated that rats exposed to an oxidant stress such as $\mathrm{NO}_{2}$ increase their lung levels of vitamin $\mathrm{E}(24,49)$. This increase is not seen in other tissues, and suggests that vitamin $\mathrm{E}$ is mobilized from other tissue sites to aid in neutralizing increased oxidants in the lung. This same phenomenon may occur in smokers who are chronically exposed to an increased burden of oxidant substances. Their lung parenchyma may take up additional vitamin $\mathrm{E}$, leaving other compartments, especially the alveolar fluid, with a relative deficiency. Since lung parenchyma is composed of alveolar macrophages as well as its component structural cells (epithelial, endothelial, and fibroblasts), the exact site of this increased uptake of vitamin $E$ is unknown. Certainly alveolar macrophages may account for much of this increase, since alveolar macrophage numbers are greatly increased in smokers, and since the present study demonstrates that their vitamin $\mathrm{E}$ content is as high as nonsmoker alveolar macrophages. In a similar type of study, McGowan et al. (50) have demonstrated that smoker alveolar macrophages contain greater amounts of vitamin $\mathrm{C}$ than nonsmoker alveolar macrophages, and accumulate higher levels of radiolabelled vitamin $C$ in vitro. Thus, in the current study it seems possible that the deficiency of vitamin $\mathrm{E}$ in the smoker alveolar fluid may reflect increased uptake by lung parenchymal cells, especially the alveolar macrophages.

An alternative explanation for this deficiency is provided by data in the present study that suggests that smoking may accelerate the oxidative metabolism of vitamin $E$ at the alveolar surface. Even in nonsmokers, the oxidation of vitamin $E$ to the quinone metabolite occurs to a greater extent in the lung compared with other tissues. The vitamin $\mathrm{E}$ quinone/vitamin $\mathrm{E}$ ratios were markedly elevated in human alveolar fluid, and both rat alveolar fluid and rat lung tissue contained ratios well in excess of the other organs examined. This process occurs to an even 
greater extent in the lungs of smokers as demonstrated by the very high vitamin $\mathrm{E}$ quinone/vitamin $\mathrm{E}$ ratio (108\%, Fig. 1) in the alveolar fluid of smokers at baseline. This presumably reflects a greater burden of oxidants in the lungs of smokers. Thus, in the current study, it seems plausible that the deficient levels of vitamin $\mathrm{E}$ in smoker alveolar fluid reflect both increased uptake by parenchymal cells, especially alveolar macrophages, as well as increased oxidation of vitamin $\mathrm{E}$ to the quinone metabolite.

The present data does not permit a conclusion that the deficient alveolar fluid vitamin $E$ level seen in smokers implies a decreased lung parenchymal level. Although the present study demonstrated a linear correlation of lavage fluid and lung parenchymal vitamin $\mathrm{E}$ levels in normal rats, this relationship, which may hold for normal man, may not be valid in chronic cigarette smokers. It is possible that their lung parenchyma has decreased, increased, or even normal levels of vitamin E.

Although the vitamin $\mathrm{E}$ quinone/vitamin $\mathrm{E}$ ratio was elevated in smokers at baseline, the absolute alveolar fluid level of vitamin E quinone was lower in smokers compared with nonsmokers. Although the present study does not reconcile this apparent paradox, there are at least two possible explanations for this discrepancy. At baseline, the amount of vitamin $E$ in the alveolar fluid available for oxidation to vitamin $E$ quinone was seven times higher in nonsmokers compared with smokers. Oxidation of even a relatively small percentage of this large pool of vitamin $E$ in nonsmoker alveolar fluid may lead to higher absolute levels of the oxidative metabolite, vitamin E quinone. Second, the metabolism of vitamin $\mathrm{E}$ quinone may be quite different in the lungs of smokers compared with nonsmokers. The uptake of quinone into lung parenchymal cells and alveolar macrophages, its metabolism to other products, and its excretion from the lung may all differ significantly in the lower respiratory tract of smokers compared with nonsmokers. Given the high vitamin E quinone/vitamin $\mathrm{E}$ ratio in smoker alveolar fluid, these differences may be important factors in explaining the lower than anticipated levels of vitamin $E$ quinone in smoker alveolar fluid.

There was no increase in smoker alveolar macrophage vitamin E levels after supplementation. The present study demonstrated that alveolar macrophages have a high baseline concentration of vitamin $\mathrm{E}, \sim 25$ times higher than previously reported values for peripheral blood neutrophils, lymphocytes, erythrocytes, and platelets $(38,51)$. Although the alveolar macrophage is a larger cell, this higher concentration cannot be accounted for solely on the basis of size. Thus, the inability to supplement the vitamin $\mathrm{E}$ content of the alveolar macrophage suggests that these cells are already maximally saturated under baseline dietary conditions, making further vitamin $\mathrm{E}$ uptake impossible.

The present study also demonstrated that vitamin E supplementation does not decrease $\mathrm{O}_{2}^{-}$release from alveolar macrophages. In related studies, Baehner et al. (43) demonstrated that after vitamin $E$ supplementation (1,600 IU/d for 2-3 wk), the $\mathrm{O}_{2}^{-}$release from neutrophils of normal volunteers was not altered. Although Baehner et al. (43) did not measure neutrophil vitamin E levels, other investigators (38) have demonstrated that neutrophil vitamin $\mathrm{E}$ content increases threefold after oral supplementation. Thus, the inability of vitamin E supplementation to decrease $\mathrm{O}_{2}^{-}$release from smoker alveolar macrophages probably reflects both the inability to increase the already high baseline vitamin $E$ levels, as well as the inability of vitamin $E$ to impact on $\mathrm{O}_{2}^{-}$release.
Alveolar fluid is a plasma ultrafiltrate that bathes and protects the alveolar surface. This fluid contains a wide spectrum of plasma proteins (52), and some of these proteins, including ceruloplasmin and transferrin, may function as lower respiratory tract antioxidants (53-55). Additional antioxidants present in alveolar fluid include surface active material (55) and vitamin $C(50,56,57)$. The present study provides evidence that vitamin $\mathrm{E}$ is also detectable in human alveolar fluid, and should be added to the list of lower respiratory tract antioxidants. Furthermore, vitamin E quinone is also an antioxidant (58-60), and its presence in alveolar fluid may afford additional protection against oxidant injury. As with vitamin E, cigarette smokers have a relative deficiency of vitamin $\mathrm{E}$ quinone in their alveolar fluid compared with nonsmokers.

The significance of low alveolar fluid vitamin E levels to the pathogenesis of emphysema in smokers is unclear at this time. However, vitamin $\mathrm{E}$ in the alveolar fluid may function to neutralize the oxidants and free radicals present in cigarette smoke as well as those released by lung inflammatory cells. Deficient levels of vitamin $\mathrm{E}$ in the thin layer of fluid lining the alveolar surface may allow an unimpeded attack on lung parenchymal cells. The cytotoxicity experiments in the present study confirm the potentially important protective role of vitamin E. Alveolar macrophage cytotoxicity for lung parenchymal cells was inversely related to lung levels of vitamin $E$. This ability of vitamin $E$ to prevent oxidant-mediated cytotoxicity has previously been noted by Martin et al. (41), who protected lung explants from oxidant damage by the addition of vitamin $E$ to the tissue culture medium. These findings suggest that vitamin $\mathrm{E}$ is an important alveolar fluid antioxidant. Deficient levels in cigarette smokers may expose the lung parenchymal cells to an increased burden of oxidants and contribute to the pathogenesis of emphysema.

\section{Acknowledgments}

This investigation was partially supported by the American Lung Association of Ohio, the general Clinical Research Center (National Institutes of Health grant RR-34), and by the Eisai Co., Ltd., of Tokyo, Japan.

\section{References}

1. Janoff, A., H. Carp, P. Laurent, and L. Raju. 1983. The role of oxidative processes in emphysema. Am. Rev. Respir. Dis. 127:S31-S38.

2. Pryor, W. A. 1981. Mechanisms and detection of pathology caused by free radicals. Tobacco smoke, nitrogen dioxide, and ozone. In Environmental Health Chemistry. J. D. McKinney, editor. Ann Arbor Science Publishers, Inc., Ann Arbor. 445-466.

3. Haagen-Smit, A. J., M. F. Brunelle, and J. Hara. 1959. Nitrogen oxide content of smokes from different types of tobacco. Arch. Industr. Hlth. 20:399-400.

4. Cohen, A. B., and H. L. James. 1982. Reduction of the elastase inhibitory capacity of alpha ${ }_{1}$-antitrypsin by peroxides in cigarette smoke. An analysis of brands and filters. Am. Rev. Respir. Dis. 126:25-30.

5. Hunninghake, G. W., J. E. Gadek, O. Kawanami, V. J. Ferrans, and R. G. Crystal. 1979. Inflammatory and immune processes in the human lung in health and disease: evaluation by bronchoalveolar lavage. Am. J. Pathol. 97:149-206.

6. Hunninghake, G. W., and R. G. Crystal. 1983. Cigarette smoking and lung destruction. Accumulation of neutrophils in the lungs of cigarette smokers. Am. Rev. Respir. Dis. 128:833-838.

7. Babior, B. M. 1978. Oxygen-dependent microbial killing by phagocytes. N. Engl. J. Med. 298:659-668, 721-725. 
8. Klebanoff, S. J. 1967. A peroxidase-mediated antimicrobial system in leukocytes. J. Clin. Invest. 46:1078. (Abstr.)

9. Gadek, J. E., G. A. Fells, and R. G. Crystal. 1979. Cigarette smoking induces functional antiprotease deficiency in the lower respiratory tract of humans. Science (Wash. DC). 206:1315-1316.

10. Carp, H., F. Miller, J. R. Hoidal, and A. Janoff. 1982. Potential mechanism of emphysema: $\alpha_{1}$-proteinase inhibitor recovered from lungs of cigarette smokers contains oxidized methionine and has decreased elastase inhibitory capacity. Proc. Natl. Acad. Sci. USA. 79:2041-2045.

11. Carp, H., and A. Janoff. 1980. Potential mediator of inflammation. Phagocyte-derived oxidants suppress the elastase-inhibitory capacity of alpha $_{1}$-proteinase inhibitor in vitro. J. Clin. Invest. 66:987-995.

12. Gadek, J. E., G. A. Fells, R. L. Zimmerman, S. I. Rennard, and R. G. Crystal. 1981. Antielastases of the human alveolar structures. Implications for the protease-antiprotease theory of emphysema. J. Clin. Invest. 68:889-898.

13. Gadek, J. E., and R. G. Crystal. 1983. $\alpha_{1}$-antitrypsin deficiency. In The Metabolic Basis of Inherited Disease. J. Stanbury, J. Wyngaarden, D. Fredrickson, J. Goldstein, and M. Brown, editors. McGraw-Hill Book Co., New York. 1450-1467.

14. Davis, W. B., M. Spatafora, J. T. Given, L. Saltzman, and R. G. Crystal. 1983. Alveolar macrophages from cigarette smokers are cytotoxic for normal lung parenchymal cells. Clin. Res. 31:415A. (Abstr.)

15. Hoidal, J. R., R. B. Fox, P. A. LeMarbe, R. Perri, and J. E Repine. 1981. Altered oxidative metabolic responses in vitro of alveolar macrophages from asymptomatic cigarette smokers. Am. Rev. Resp. Dis. 123:85-89.

16. Lentz, P. E., and N. R. DiLuzio. 1974. Peroxidation of lipids in alveolar macrophages. Production by aqueous extracts of cigarette smoke. Arch. Environ. Health. 28:279-282.

17. Combs, G. F., T. Noguchi, and M. L. Scott. 1975. Mechanisms of action of selenium and vitamin $\mathrm{E}$ in protection of biological membranes. Fed. Proc. 34:2090-2095.

18. Salked, R. M. 1975. Safety and tolerance of high-dose vitamin $\mathrm{E}$ administration in man: a review of the literature. F. Hoffman-LaRoche Co., Ltd., Basle. 1-52.

19. Bieri, J. G., L. Corash, and V. S. Hubbard. 1983. Medical uses of vitamin E. N. Engl. J. Med. 308:1063-1071.

20. Witting, L. A. 1980. Vitamin E and lipid antioxidants in freeradical initiated reactions. In Free Radicals in Biology, Vol. IV. W. A. Pryor, editor. Academic Press, Inc., Orlando. 295-319.

21. McCay, P. B., and M. M. King. 1980. Vitamin E: its role as a biologic free radical scavenger and its relationship to the microsomal mixed function oxidase system. In Vitamin E: A Comprehensive Treatise. L. Machlin, editor. Marcel Dekker, Inc., New York. 289-317.

22. Ward, J. A., and R. J. Roberts. 1984. Vitamin E inhibition of the effects of hyperoxia on the pulmonary surfactant system of the newborn rabbit. Ped. Res. 18:329-334.

23. Bucher, J. R., and R. J. Roberts. 1982. Effects of $\alpha$-tocopherol treatment on newborn rat lung development and injury in hyperoxia. Ped. Pharmacol. 2:1-9.

24. Sevanian, A., N. Elsayed, and A. D. Hacker. 1982. Effects of vitamin $\mathrm{E}$ deficiency and nitrogen dioxide exposure on lung lipid peroxidation: use of lipid epoxides and malonaldehyde as measures of peroxidation. J. Toxicol. Environ. Health. 10:743-756.

25. Evans, M. J., L. J. Cabral-Anderson, N. P. Dekker, and G. Freeman. 1981. The effects of dietary antioxidants on $\mathrm{NO}_{2}$-induced injury to type 1 alveolar cells. Chest. 80:5S-8S.

26. Roehm, J. N., J. G. Hadley, and D. B. Menzel. 1972. The influence of vitamin E on the lung fatty acids of rats exposed to ozone. Arch. Environ. Health. 24:237-242.

27. Fletcher, B. L., and A. L. Tappel. 1973. Protective effects of dietary $\alpha$-tocopherol in rats exposed to toxic levels of ozone and nitrogen dioxide. Environ. Res. 6:165-175.

28. Sato, S., M. Kawakami, S. Maeda, and T. Takishima. 1976. Scanning electron microscopy of the lungs of vitamin E-deficient rats exposed to a low concentration of ozone. Am. Rev. Respir. Dis. 113: 809-821.
29. Block, E. R. 1979. Potentiation of acute paraquat toxicity by vitamin E deficiency. Lung. 156:195-203.

30. Boyd, M. R., G. L. Catignani, H. A. Sasame, J. R. Mitchell, and A. W. Stiko. 1979. Acute pulmonary injury in rats by nitrofurantoin and modification by vitamin E, dietary fat, and oxygen. Am. Rev. Respir. Dis. 120:93-99.

31. Kornbrust, D. J., and R. D. Mavis. 1980. Relative susceptibility of microsomes from lung, heart, liver, kidney, brain and testes to lipid peroxidation: correlation with vitamin E content. Lipids. 15:315-322.

32. Gairola, C., D. H. Matulionis, and M. J. Reasor. 1983. Chlorphentermine-induced alterations in the lungs of vitamin $\mathrm{E}$ deficient and supplemented rats: 1. Biochemical and morphometric analysis of the pulmonary response. Exp. Molec. Path. 38:368-379.

33. Chow, C. K., L. H. Chen, R. R. Thacker, and R. B. Griffith. 1984. Dietary vitamin $E$ and pulmonary biochemical responses of rats to cigarette smoking. Environ. Res. 34:8-17.

34. Machlin, L. J., and E. Gabriel. 1982. Kinetics of tissue $\alpha$-tocopherol uptake and depletion following administration of high levels of vitamin E. Ann. NY Acad. Sci. 393:48-60.

35. Draper, H. H., J. G. Bergan, M. Chiu, A. S. Csallany, and A. V. Boaro. 1964. A further study of the specificity of the vitamin $E$ requirement for reproduction. J. Nutr. 84:395-400.

36. Buttriss, J. L., and A. T. Diplock. 1984. High performance liquid chromatography methods for vitamin E in tissues. Methods Enzymol. 105:131-138.

37. Stump, D. D., E. F. Roth, and H. S. Gilbert. 1984. Simultaneous determination by high performance liquid chromatography of tocopherol isomers, $\alpha$-tocopheryl quinone, and cholesterol in red blood cells and plasma. J. Chromatog. 306:371-376.

38. Hatam, L. J., and H. J. Kayden. 1979. A high performance liquid chromatographic method for the determination of tocopherol in plasma and cellular elements of the blood. J. Lipid Res. 20:639-645.

39. Babior, B. M., R. S. Kipnes, and J. T. Curnutte. 1973. Biological defense mechanisms. The production by leukocytes of superoxide, a potential bactericidal agent. J. Clin. Invest. 52:741-744.

40. Margoliash, E., and M. Frohwirt. 1959. Spectrum of horse-heart cytochrome C. Biochem. J. 71:570-572.

41. Martin, W. J., J. E. Gadek, G. W. Hunninghake, and R. G. Crystal. 1981. Oxidant injury of lung parenchymal cells. J. Clin. Invest. 68:1277-1288.

42. Baker, H., O. Frank, B. DeAngelis, and S. Feingold. 1980. Plasma tocopherol in man at various times after ingesting free or acetylated tocopherol. Nutr. Rep. Intern. 21:531-536.

43. Baehner, R. L., L. A. Boxer, L. M. Ingraham, C. Butterick, and R. A. Haak. 1982. The influence of vitamin $\mathrm{E}$ on human polymorphonuclear cell metabolism and function. Ann. NY Acad. Sci. 393:237-250.

44. Steiner, M., and J. Anastasi. 1976. Vitamin E: an inhibitor of the platelet release reaction. J. Clin. Invest. 57:732-737.

45. Corash, L., S. Spielberg, C. Bartsocas, L. Boxer, R. Steinherz, M. Sheetz, M. Egan, J. Schlessleman, and J. D. Schulman. 1980. Reduced chronic hemolysis during high dose vitamin $\mathrm{E}$ administration in Mediterranean type glucose-6-phosphate dehydrogenase deficiency. $N$. Engl. J. Med. 303:416-420.

46. Hittner, H. M., L. B. Godio, A. J. Rudolph, J. M. Adams, J. A. Garcia-Prats, Z. Friedman, J. A. Kautz, and W. A. Monaco. 1981. Retrolental fibroplasia: efficacy of vitamin $\mathrm{E}$ in a double-blind clinical study of preterm infants. N. Engl. J. Med. 305:1365-1371.

47. Chow, C. K., and A. L. Tappel. 1972. An enzymatic protective mechanism against lipid peroxidation damage to lungs of ozone-exposed rats. Lipids. 7:518-524.

48. Thomas, H. V., P. K. Mueller, and R. L. Lyman. 1968. Lipoperoxidation of lung lipids in rats exposed to nitrogen dioxide. Science (Wash. DC). 159:532-534.

49. Elsayed, N. M., and M. G. Mustafa. 1982. Dietary antioxidants and the biochemical response to oxidant inhalation. I. Influence of dietary vitamin $\mathbf{E}$ on the biochemical effects of nitrogen dioxide exposure in rat lung. Toxicol. Appl. Pharmacol. 66:319-328.

50. McGowan, S. E., C. M. Parenti, J. R. Hoidal, and D. E. Nie- 
woehner. 1984. Ascorbic acid content and accumulation by alveolar macrophages from cigarette smokers and nonsmokers. J. Lab. Clin. Med. 104:127-134.

51. Vatassery, G. T., A. M. Krezowski, and J. H. Eckfeldt. 1983. Vitamin E concentrations in human blood plasma and platelets. Am. J. Clin. Nutr. 37:1020-1024.

52. Bell, D. Y., J. A. Haseman, A. Spock, G. McLennan, and G. E. R. Hook. 1981. Plasma proteins of the bronchoalveolar surface of the lungs of smokers and nonsmokers. Am. Rev. Respir. Dis. 124:7279.

53. Galdston, M., V. Levytska, M. S. Schwartz, and B. Magnusson. 1984. Ceruloplasmin. Increased serum concentration and impaired antioxidant activity in cigarette smokers and ability to prevent suppression of elastase inhibitory capacity of alpha, -proteinase inhibitor. Am. Rev. Respir. Dis. 129:258-263.

54. Ward, P. A., G. O. Till, R. Kunkel, and C. Beauchamp. 1983. Evidence for role of hydroxyl radical in complement and neutrophildependent tissue injury. J. Clin. Invest. 72:789-801.
55. Cantin, A., G. Fells, J. T. Given, and R. G. Crystal. 1983. Antioxidant protection of the lower respiratory tract by components of epithelial lining fluid. Clin. Res. 31:511A. (Abstr.)

56. Willis, R. J., and C. C. Kratzing. 1974. Ascorbic acid in rat lung. Biochem. Biophys. Res. Commun. 59:1250-1253.

57. Snyder, A., L. Skoza, and Y. Kikkawa. 1983. Comparative removal of ascorbic acid and other airway substances by sequential bronchoalveolar lavages. Lung. 161:111-121.

58. Lindsey, J. A., H. Zhang, H. Kaseki, N. Morisaki, T. Sato, and D. G. Cornwell. 1985. Fatty acid metabolism and cell proliferation. VII. Antioxidant effects of tocopherols and their quinones. Lipids. 20:151157.

59. Morisaki, N., J. A. Lindsey, J. M. Stitts, H. Zhang, and D. G. Cornwell. 1984. Fatty acid metabolism and cell proliferation. V. Evaluation of pathways for the generation of lipid peroxides. Lipids. 19:381394.

60. Gavino, V. C., J. S. Miller, S. O. Ikharebha, G. E. Milo, and D. G. Cornwell. 1981. Effect of polyunsaturated fatty acids and antioxidants on lipid peroxidation in tissue cultures. J. Lipid Res. 22:763-769. 